\title{
Basic Skin Care and Topical Therapies for Atopic Dermatitis: Essential Approaches and Beyond
}

\author{
Sala-Cunill $\mathrm{A}^{1^{*}}$, Lazaro $\mathrm{M}^{2}$, Herráez $\mathrm{L}^{3}$, Quiñones $\mathrm{MD}^{4}$, Moro-Moro $\mathrm{M}^{5}$, Sanchez $\mathrm{I}^{6}$, On behalf of the Skin \\ Allergy Committee of Spanish Society of Allergy and Clinical Immunology (SEAIC)
}

\begin{abstract}
'Allergy Section, Internal Medicine Department, Hospital Universitario Vall d'Hebron, Barcelona, Spain
${ }^{2}$ Allergy Department, Hospital Universitario de Salamanca, Alergoasma, Salamanca, Spain

${ }^{3}$ Allergy Department, Hospital Universitario 12 de Octubre, Madrid, Spain

${ }^{4}$ Allergy Section, Hospital Monte Naranco, Oviedo, Spain

${ }^{5}$ Allergy Department, Hospital Universitario Fundación Alcorcón, Alcorcón, Madrid, Spain

${ }^{6}$ Clínica Dermatología y Alergia, Badajoz, Spain

*Both authors contributed equally to the manuscript
\end{abstract}

J Investig Allergol Clin Immunol 2018; Vol. 28(6): 379-391

doi: 10.18176/jiaci.0293

\begin{abstract}
Atopic dermatitis (AD) is a recurrent and chronic skin disease characterized by dysfunction of the epithelial barrier, skin inflammation, and immune dysregulation, with changes in the skin microbiota and colonization by Staphylococcus aureus being common. For this reason, the therapeutic approach to AD is complex and should be directed at restoring skin barrier function, reducing dehydration, maintaining acidic $\mathrm{pH}$, and avoiding superinfection and exposure to possible allergens. There is no curative treatment for AD. However, a series of measures are recommended to alleviate the disease and enable patients to improve their quality of life. These include adequate skin hydration and restoration of the skin barrier with the use of emollients, antibacterial measures, specific approaches to reduce pruritus and scratching, wet wrap applications, avoidance of typical AD triggers, and topical anti-inflammatory drugs. Anti-inflammatory treatment is generally recommended during acute flares or, more recently, for preventive management. Nevertheless, the selection of the pharmacologic agent, as well as its potency, duration, and frequency of application must be in accordance with the severity of the disease and the distribution and type of the lesion. The objectives of this review are to emphasize the importance of basic skin care and to describe current and novel topical therapies for AD.
\end{abstract}

Key words: Eczema. Topical treatment. Atopic dermatitis. Pruritus. Emollients.

\section{Resumen}

La dermatitis atópica (DA) es una enfermedad cutánea crónica y recurrente que se caracteriza por la existencia de una disfunción de la barrera epitelial, un proceso inflamatorio cutáneo, una alteración del sistema inmune y posibles cambios en la microbiota cutánea, siendo frecuente una posible colonización por Estafilococo aureus. Por ello, el abordaje terapéutico de la DA es complejo y debe de estar enfocado principalmente hacia la restauración de la barrera cutánea, la reducción de la deshidratación, el mantenimiento del PH ácido y la evitación de posibles sobreinfecciones y exposiciones a diferentes fuentes alergénicas. Actualmente no existe tratamientos curativos para la DA. Sin embargo, con el fin de aliviar la enfermedad y que mejore la calidad de vida de los pacientes, se recomiendan una serie de medidas que incluyen una adecuada hidratación y restauración de la barrera cutánea gracias a la aplicación de emolientes, medidas antibacterianas, reducción del picor y del rascado mediante determinados abordajes específicos, la aplicación de vendajes húmedos, la evitación de los desencadenantes de la DA y una terapia tópica antiinflamatoria adecuada. Los tratamientos anti-inflamatorios se recomiendan habitualmente durante las reagudizaciones y, más recientemente, como tratamiento preventivo. Sin embargo, dependiendo de la gravedad de la enfermedad, la distribución o el tipo de lesión, se seleccionará el agente farmacológico, su potencia, la duración y frecuencia necesaria de aplicación. El objetivo principal de esta revisión es resaltar la importancia del cuidado básico de la piel, además de describir los tratamientos tópicos, tanto actuales como emergentes, que existen para el abordaje de la dermatitis atópica.

Palabras clave: Eczema. Tratamiento tópico. Dermatitis atópica. Prurito. Emolientes. 


\section{Introduction}

Atopic dermatitis (AD) is a recurrent and chronic skin disease characterized initially by dry and very itchy skin. Onset tends to be at an early age [1]. It is estimated to affect $20 \%$ of the infant population in industrialized cities [2], where it is more prevalent than in rural areas. It negatively affects the quality of life of patients and their relatives.

$\mathrm{AD}$ is characterized by dysfunction of the epithelial barrier, skin inflammation, and immune dysregulation, with changes in the skin microbiota and colonization by Staphylococcus aureus being common. It is the first step of the so-called atopic march, which is a well-described sequential appearance of $\mathrm{AD}$, rhinitis, and asthma in affected patients [3]. Its pathophysiology is multifactorial and polygenic [4].

\section{Pathophysiological Mechanisms of Atopic Dermatitis}

The epidermis, especially the stratum corneum, is the body's first line of defense against the environment, minimizes loss of water from the body, and protects us against harmful environmental effects. Its main protein is filaggrin, which is synthesized as profilaggrin, whose gene is located on chromosome 1q21 [5]. Filaggrin monomers are produced during the final phase of differentiation of the keratinocytes, and their degradation generates a series of products that act as an osmotic barrier promoting water retention. These products, known as natural moisturizing factors [6], contribute to the maintenance of the acidic $\mathrm{pH}$ of the skin, which has an antimicrobial effect and contributes to the functionality of the enzymes involved in the metabolism of ceramides and differentiation of the corneal layer [4]. The recently described filaggrin gene mutations [7,8] are considered one of the main risk factors for the development of $\mathrm{AD}$. Other mutations associated with the risk of $\mathrm{AD}$ include a polymorphism in the vitamin $\mathrm{D}$ receptor gene, which was studied in a Turkish population [9].

Lipids also play an important role in the function of the stratum corneum and are responsible for the production of ceramides. Any alteration in the arrangement of ceramides leads to poor functioning of the skin barrier, as occurs with filaggrin [10,11].

Both innate and adaptive immunity contribute to the pathophysiology of AD. In the case of innate immunity, it has been observed that IL-25, IL-33, and thymic stromal lymphopoietin are upregulated in patients with AD [12]. These epithelial cytokines are associated with the accumulation of type 2 innate lymphoid cells. In addition, a broad array of other innate immune cells including dendritic cells, mast cells, basophils, and eosinophils participate in the pathophysiology of AD [13].

Adaptive immunity also participates in the pathophysiology of $\mathrm{AD}$. Initial $\mathrm{T}_{\mathrm{H}} 2$ polarization and an increase in the expression of cytokines such as IL-4, IL-5, and IL-13 play an important role in the disease. The paradigm of exclusively $\mathrm{T}_{\mathrm{H}} 2$ polarization has recently been revised, since other lymphocyte populations $\left(\mathrm{T}_{\mathrm{H}} 17\right.$ and $\left.\mathrm{T}_{\mathrm{H}} 22\right)$ have been reported to participate in $\mathrm{AD}[14,15]$. In addition to $\mathrm{CD}^{+}$lymphocytes, $\mathrm{CD} 8^{+}$ lymphocytes have been found in the skin of patients with AD. These release IFN- $\gamma$, IL-13, and IL-22 [16], all of which impact innate immunity by suppressing antimicrobial peptides and have a direct effect on skin barrier integrity by suppressing differentiation proteins such involucrin, filaggrin, and loricrin.

The alteration of the skin microbiota, which results from an imbalance between the number of commensal and pathogenic bacteria, could play a critical role in the development of AD. The skin is colonized by $S$ aureus in more than $90 \%$ of patients with $\mathrm{AD}$, compared with $5 \%$ of healthy patients. This bacterial colonization appears to be caused by an alteration in the production of filaggrin owing to increased $\mathrm{pH}$ in the stratum corneum and the reduction of antimicrobial peptides in the epidermis [17].

Therefore, the pathophysiological mechanisms of AD are very complex and include genetic factors, an alteration in the structural barrier, altered immune regulation, and changes in the skin microbiota [18]. For this reason, the therapeutic approach to $\mathrm{AD}$ is complex and should be directed at restructuring the epithelial barrier, reducing dehydration, maintaining acidic $\mathrm{pH}$, and avoiding superinfection and exposure to possible allergens. Multidisciplinary management is necessary and often requires the participation of psychologists, nursing personnel, and dieticians in addition to physicians [19].

There is no curative treatment for AD. However, a series of available measures can help to alleviate the disease and enable patients to improve their quality of life (Table 1). This review focuses on basic skin care and the main topical treatments in $\mathrm{AD}$.

\section{Basic and Topical Skin Care: Essential Approaches in Atopic Dermatitis}

To provide the best basic care, it is essential to assess the condition of the skin and know all the vehicles of the emollient moisturizing products so as to match treatment to the stage of $\mathrm{AD}[20]$. An emollient is a product that promotes the occlusion of the skin and prevents water loss; a moisturizer is a product that keeps the skin hydrated [21]. Many products (emollients, moisturizers, and emollient moisturizers) are available in presentations such as creams, lotions, and balms, whose consistency varies depending on the composition. Therefore, a prior assessment of the condition of the skin is important when choosing the correct treatment (Table 2).

\subsection{Hygiene and Skin Hydration}

Daily hygiene with warm water baths $\left(30^{\circ}-33^{\circ}\right)$ for a maximum of 5-10 minutes is recommended. Detergents and the use of a sponge should be avoided. The aim of the bath is to clean the skin, eliminate scabs, relax the patient, decrease pruritus, and facilitate the application of drugs. The use of a shower gel in the form of oil with acidic $\mathrm{pH}$ or neutral or acidic detergents is the most widely recommended approach, since these agents maintain the $\mathrm{pH}$ of the skin and produce less irritation of the corneal layer, thus enabling fatty acids to be retained. It is important to dry off with a cotton towel using soft dabs, avoid scratching, and proceed to the immediate application of the emollient moisturizing 
Table 1. Recommendations for Therapeutic Regimens According to the Severity of Atopic Dermatitis

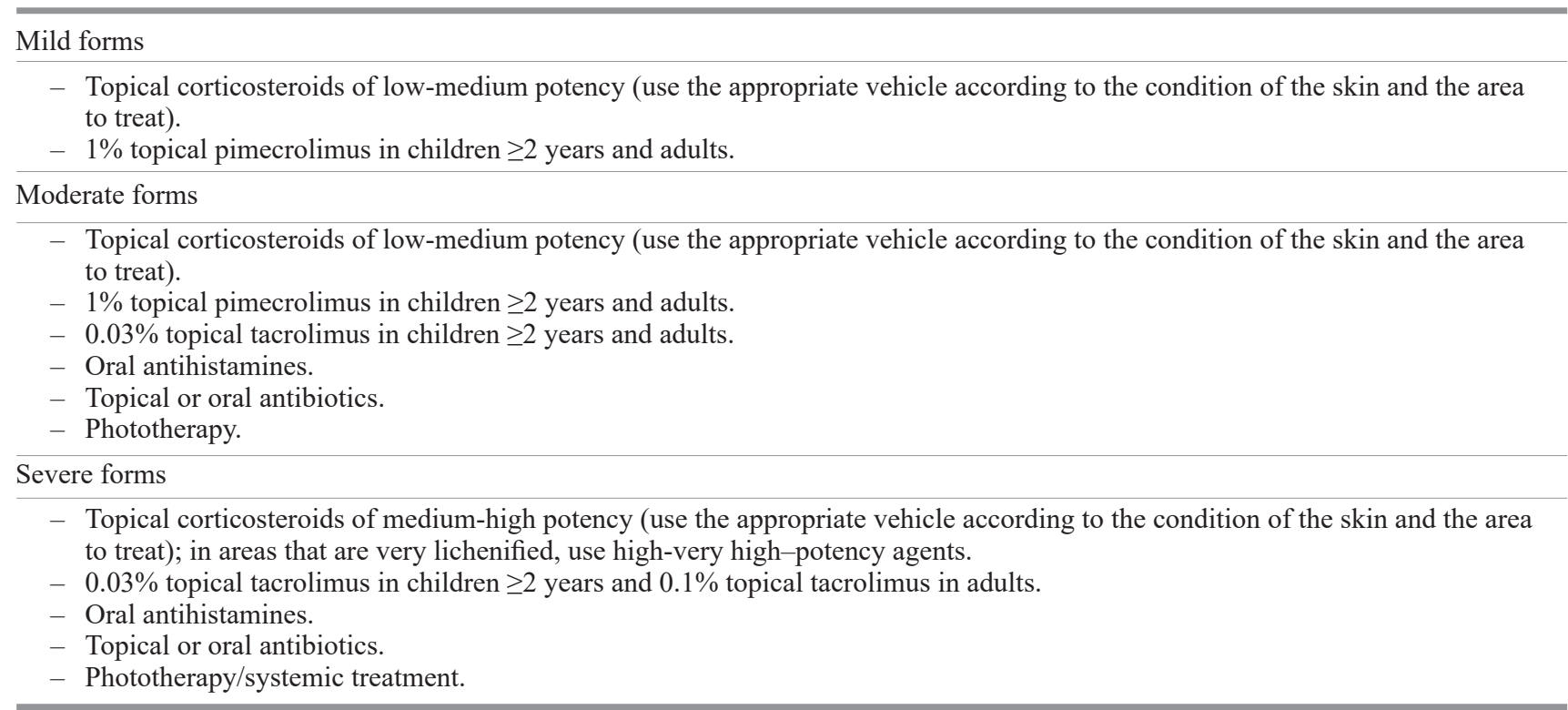

\section{Table 2. Treatment of Atopic Dermatitis According to Skin Condition}

Acute phase (erythema, edema, vesiculation, and exudation)

- Acute phase (erythema, edema, vesiculation, and exudation)

- If exudative lesions are present: astringent compresses or baths with an aqueous solution of potassium permanganate at 1:10 000 or a solution of zinc, copper, and silica

- Hydration in the form of lotion

- If topical corticosteroids are needed, apply low-potency agents and as a lotion

Subacute phase (erythema and minimal vesiculation)

- Hydration in the form of creams or lotions

- If topical corticosteroids are needed, apply medium-potency agents and as a cream

- Topical immunomodulators as a cream

Chronic phase (lichenification, intense xerosis, and scaling)

- Hydration in the form of creams or ointments

- Prepare wet wraps with physiological saline and add corticosteroids to increase the anti-inflammatory effect. In lichenified areas, increase occlusive dressings

- If topical corticosteroids are needed, apply as an ointment or balm

- Topical immunomodulators as a cream or ointment

- Add urea as a keratolytic agent in very lichenified areas or areas with scaling

- Preparations with tar in very dry or lichenified areas may also be added

product within 3 minutes. Emollients with barrier action rich in ceramides [22], which can improve the function of the skin barrier, and new creams and soaps with acidic $\mathrm{pH}[23]$ can reduce the severity and flares of $\mathrm{AD}$ and prevent complications.

\subsection{Antiseptics}

In the event of a bacterial superinfection due to $S$ aureus, which is very common in patients with $\mathrm{AD}$, topical treatment with mupirocin is recommended. In addition, twice-weekly $6 \%$ bleach baths (half a cup of bleach in 180 liters of water) have been shown to be efficacious in a randomized, placebo- controlled study [24]. Patients in the active group took twiceweekly bleach baths and applied topical nasal mupirocin 5 days per month; patients in the placebo group took water baths and applied intranasal petrolatum. A significant reduction $(P=.004)$ was observed in the severity of AD compared with the placebo group. Dermatophyte infections may also be common (the most frequent being that by Malassezia sympodialis), especially in seborrheic areas such as the scalp, face, and neck. Treatment in these cases is topical ketoconazole applied as a cream (1 application every 12 hours until symptoms resolve) and as a gel if the scalp is affected ( 1 application twice per week, leaving it to take effect for 3-5 minutes until symptoms resolve) [25]. 
If extensive areas of the skin are affected, systemic treatment with ketoconazole may be considered. In the event of nail involvement, ciclopirox olamine applied once every 12-24 hours until regeneration has been reported to be beneficial [26].

\subsection{Preparations With Tar}

Although tar preparations have been used for many years, they have not been evaluated in randomized, placebocontrolled studies $[27,28]$. In any case, given that they have fewer adverse effects than corticosteroids and new, bettertolerated preparations with less odor and staining have been developed, it can be effective to use creams or ointments with $0.5 \%-5 \%$ coal tar (mineral tar) for the chronic phase or in very lichenified areas [29]. Application in areas of acute inflammation is not recommended, since these may become further irritated. In general, the tar preparation is applied at night and taken off in the morning with bathing. It can also be used once or twice weekly as a shower gel (adding it to water, with anti-itching effect) and as a $0.5 \%-3 \%$ shampoo when AD affects the scalp [30]. Exposure to sun must be avoided for at least 24 hours following application of the treatment, since tar is photosensitive.

\subsection{Wet Compresses for Exudative Lesions}

When the lesions are exudative, they should be dried using compresses or astringent baths with an aqueous solution of potassium permanganate 1:10 000 (compounded formula). The preparation of between 20 and 100 sachets of $0.1 \mathrm{~g}$, each diluted in a liter of water, is recommended. This is applied twice or 3 times daily using wet compresses for 20 minutes until the exudative lesion dries out. Solutions with zinc sulfate, copper, or silica can also be applied once or twice per day with the same objective. During the exudative period, creams should be avoided, as they are not absorbed and can aggravate the lesions [25].

\subsection{Wet Wrap Therapy}

Wet wraps with physiological saline are useful in $\mathrm{AD}$ with chronic lesions and lesions that are refractory to other treatments. To increase local action, they can be used with diluted topical corticosteroids (TCSs) or emollients if there are no signs of infection $[31,32]$. Wet wraps also serve to protect the skin against scratching and prevent excoriation. Application for extended periods can cause maceration and folliculitis. A greater tendency towards local infections is observed when the wraps are used with TCSs than when they are used with emollient moisturizers only [33]. The dressings are prepared by submerging them in a container with warm water and placing them on the area of the skin with lesions, where the prescribed topical treatment has previously been applied. A dry dressing is placed on this first moist layer.

\subsection{Urea}

Urea facilitates desquamation by regulating the expression of specific genes involved in the differentiation of keratinocytes, the synthesis of lipids, and the production of antimicrobial peptides, thus improving barrier function and, probably, antimicrobial defense [34]. Urea is also anti-itching. Its potency is lower than that of salicylic acid, and it is used in concentrations that range from $3 \%$ to $30 \%$. If the concentration is elevated, it may irritate some patients with $\mathrm{AD}$. A recent, multicenter, randomized, double-blind study [35] with 5\% urea cream showed that in the treatment group, the symptom-free period was significantly longer than in the group that received the reference cream.

\subsection{Antipruritus Creams}

\subsubsection{Polidocanol}

Polidocanol is a fatty alcohol ethoxylate with local anesthetic properties that are included in the formulation of moisturizing and emollient preparations for relief of atopic pruritus.

\subsubsection{Naltrexone as a Cream}

In a comparative study with placebo, the application of a cream with $1 \%$ naltrexone (a $\mu$-opioid receptor antagonist) for 2 weeks demonstrated better and faster control of pruritus than placebo, with significant differences $(P<.05)$ [36]. It can also be administered orally in cases of very intense pruritus.

\subsection{3. СТ327}

CT327 inhibits capsaicin responses in sensory neurons and improves itching in psoriasis. This agent has completed a phase II clinical trial in AD (NCT01808157), although the results have not yet been published [37].

\section{New Topical Treatments}

Many new topical therapies are currently being developed. Below, we present the most important treatments for which evidence is available from randomized controlled trials (RCTs).

\subsection{Cream With 5\% Vitreoscilla filiformis}

Vitreoscilla filiformis (Vf) is a photosynthetic bacterium. When administered in a cream, it is well tolerated and has few adverse effects (mild burning sensation a few minutes after administration) [38]. A randomized, double-blind study that compared $5 \%$ Vf cream with the vehicle, twice per day for 4 weeks, with a cream with the vehicle only demonstrated that the group of patients who had received the cream with Vf presented a statistically significant improvement in SCORAD value, pruritus, sleep loss, and colonization by $S$ aureus, compared with the control group [39]. A recent murine model revealed that the application of Vf lysates activates immunomodulatory mechanisms that reduce inflammation. This finding implies new knowledge about the relationship between bacteria and host immunity [40].

\subsection{Cream With Phosphodiesterase-4 Inhibitors}

There are 11 families of phosphodiesterase enzymes, each with a different degree of selectivity. Phosphodiesterase-4 inactivates cyclic adenosine monophosphate (cAMP), thus increasing the production of proinflammatory prostaglandins and cytokines. It is expressed in cells of the immune system, 
as well as in keratinocytes and fibroblasts, and is more active in patients with $\mathrm{AD}$ [37]. In 2 double-blind, placebo-controlled studies [41], cipamfylline and CP80,633 significantly reduced the severity of AD compared with a cream with the vehicle only and a petroleum jelly cream, respectively. However, in another study, lower efficacy was observed for cipamfylline than with hydrocortisone 17-butyrate. This novel therapy offers an alternative to TCSs and topical calcineurin inhibitors (TCIs) in the treatment of AD. Crisaborole (AN2728) is an approved phosphodiesterase-4 inhibitor. The topical form is applied in a $2 \%$ ointment (twice daily). In a recent advanced phase study, it was shown to have encouraging results in children and adults with $\mathrm{AD}[42,43]$, A long-term safety study with crisaborole $2 \%$ ointment demonstrated efficacy, safety, and good tolerance in mild-to-moderate AD [44]. RVT 501 and MM36 are phosphodiesterase-4 inhibitors that have demonstrated efficacy in patients with $\mathrm{AD}$ in RCTs [45].

\subsection{Janus Kinase Inhibitors}

Janus kinase (JAK) and signal transducer and activator of transcription form a signal transduction pathway. Interleukins involved in AD, such as IL-4, IL-13, and IL-31, use this pathway and amplify the $\mathrm{T}_{\mathrm{H}} 2$ cell response. They also downregulate structural epidermal proteins, eg, filaggrin, loricrin, and involucrin, thus diminishing the skin barrier function. Tofacitinib is a small molecule that inhibits JAK 1 and JAK 3 and, in theory, reduces expression of these interleukins and, therefore, reduces inflammation [46]. A recent phase IIa clinical trial showed that topical $2 \%$ tofacitinib ointment is relatively safe and superior to vehicle in the treatment of AD. However, further studies are necessary [47]. Other JAK inhibitors are available, although in oral formulation, eg, baricitinib (phase II clinical trial completed) and upadacitinib (phase II recruiting) with promising results (baricitinib is a small molecule inhibiting both JAK 1 and JAK2) [48].

\section{4. $C R T_{H} 2$ Antagonists-Q301}

Chemoattractant receptor-homologous molecule $\left(\mathrm{CRT}_{\mathrm{H}} 2\right)$ is a transmembrane prostaglandin D2 receptor expressed on $\mathrm{T}_{\mathrm{H}} 2$ lymphocytes. When stimulated, it leads to activation of $\mathrm{T}_{\mathrm{H}} 2$ cells and chemotaxis. This new topical cream (Q301) is thought to antagonize the $\mathrm{CRT}_{\mathrm{H}} 2$ receptor and decrease the $\mathrm{T}_{\mathrm{H}} 2$ response in $\mathrm{AD}$. A phase II RCT comparing Q301 with vehicle in patients with moderate to severe $A D$ was recently completed (NCT02426359), although the results have not yet been published [37]. In addition, 2 phase II clinical trials with $\mathrm{CRT}_{\mathrm{H}} 2 \mathrm{mAb}$ have reported promising results (fevipiprant and timapiprant) [47].

\subsection{Cream With Vitamin $B_{12}$}

Vitamin $B_{12}$ inhibits the production of inflammatory cytokines produced by $\mathrm{T}$ lymphocytes, because it is an effective scavenger of nitric oxide and therefore represents a potentially effective treatment for AD [49]. In a phase III, multicenter, randomized, placebo-controlled clinical trial, topical vitamin $\mathrm{B}_{12}$ applied twice per day for 8 weeks on the affected areas proved to be effective in reducing the extension and severity of $\mathrm{AD}(P<.001)$, with no adverse effects and with good tolerance [50]. Similar results were recently obtained in a hemi-body randomized, controlled, single-blind, intra-patient left-to-right study with topical vitamin $\mathrm{B}_{12}$ barrier cream (MB12) vs glycerol-petrolatum-based emollient cream. The SCORAD result and itching improved significantly in the group treated with MB12 $(P<.001)$, suggesting that MB12 could be a new option for the treatment of AD [50].

\section{Antiinflammatory Topical Therapy for Atopic Dermatitis}

The 2 main classes of topical antiinflammatory drugs for the treatment of $\mathrm{AD}$ are TCSs and TCIs.

\subsection{Topical Corticosteroids}

TCSs are the first-line pharmacological treatment for AD. They have antiinflammatory, immunosuppressive, antiproliferative, and vasoconstrictive effects [51]. The mechanism of the antiinflammatory activity of TCSs is not fully known. The drugs suppress various components of the inflammatory pathway, including the release of inflammatory cytokines, and act on various cells of the immune system, from $\mathrm{T}$ lymphocytes, monocytes, and macrophages to dendritic cells and their precursors [52]. TCSs disseminate through cell membranes and interact with the cell receptors of dermal cells. The potency of TCSs is determined by the vasoconstriction [53] generated, which is measured as the degree and the duration of skin clearance following its application. As a national reference guide, 4 groups have been classified based on their potency, namely, very high (class IV), high (class III), moderate (class II), and low (I), as shown in Table 3. Prescribers should be aware of other guidelines, such as European guidelines [54] and American guidelines [55], which classify the potency of TCSs and drug formulations differently. The efficacy of treatment with TCSs depends on factors such as potency, which responds to specific modifications of the TCS molecule, in addition to the concentration of the active ingredient. For example, $1 \%$ hydrocortisone acetate is a low-potency TCS, whereas $0.1 \%$ hydrocortisone butyrate is a high-potency TCS. The pharmaceutical form of the drug facilitates its penetration, thus affecting efficacy. Correct application, sufficient dose, the use or absence of an occlusive dressing, the prior condition of the skin, and the anatomical area of application determine the absorption of TCSs and should be taken into account to minimize TCS-related adverse effects [55].

\subsubsection{Selection of Topical Corticosteroids for AD}

The appropriate choice of a TCS for the treatment of AD can be complex, since the number of clinical studies that compare 2 or more preparations are limited. Before prescribing this treatment, factors that influence its effectiveness and the risk of adverse effects must be considered. It is recommended to apply low- to intermediate-potency TCSs on the face and genital areas, although other higher potency TCSs can be applied on the rest of the body surface [56]. As a general recommendation in children, low-potency TCSs can be 
Table 3. Classification of Corticosteroids According to Their Potency and the Vehicle Available (Modified From Martindale [20])

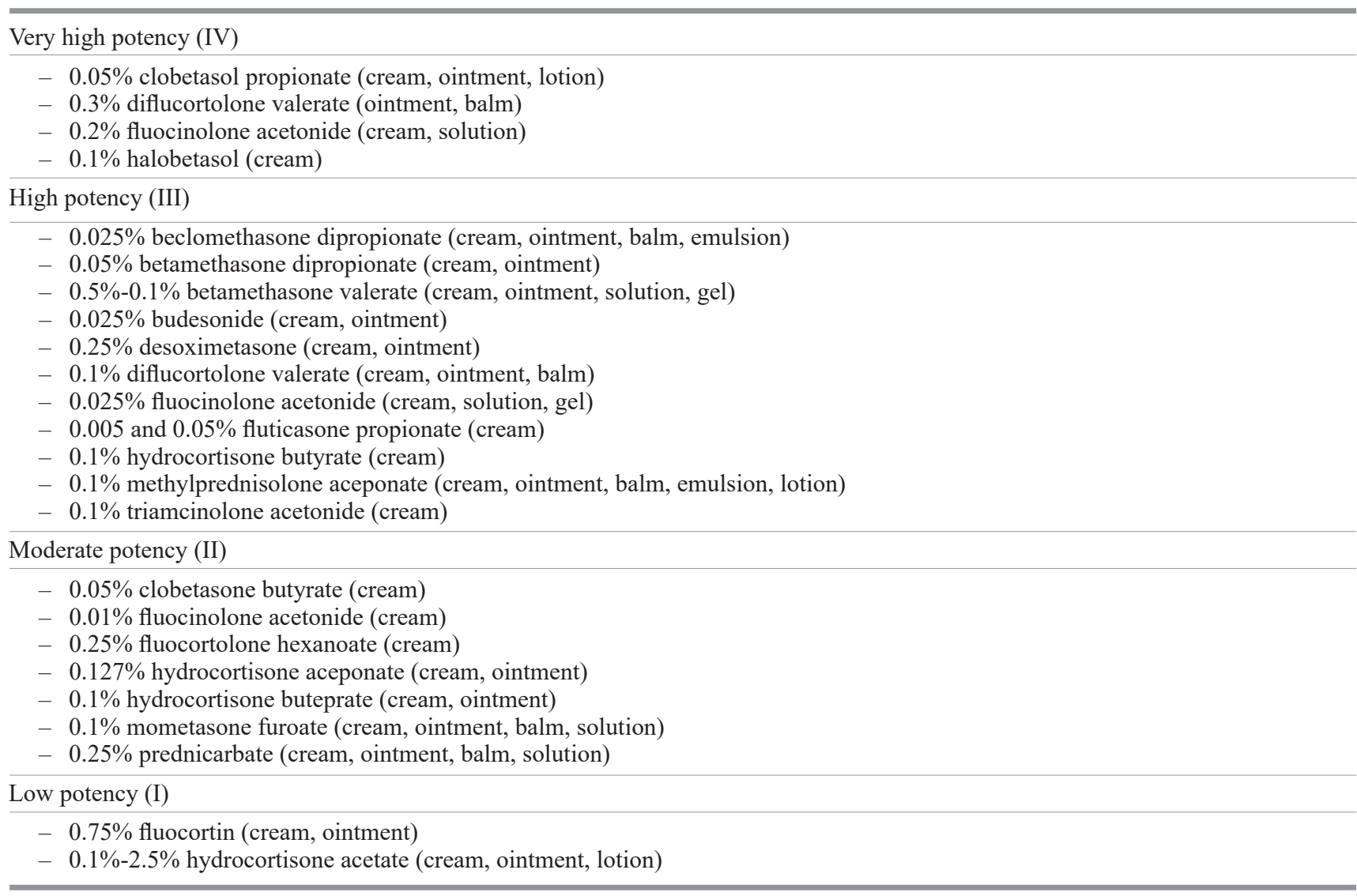

applied on any area [57]. Areas with lichenification require the application of more potent TCSs for a longer period. The vehicle in which a TCS is available may modify its potency and must be taken into consideration depending on the anatomical area of application, the age of the patient, and the severity of AD. Ointments provide more uniform coverage and penetration than creams, which, nevertheless, are applied more easily in areas, such as skinfolds and the genitals. Foams, lotions, and gels are easier to apply in hair-bearing areas and are preferred in oily areas [58]. The preferences of the patient for one or other formulation should be taken into consideration to facilitate adherence to treatment.

\subsubsection{Frequency of Application}

According to current guidelines, twice-daily application of corticosteroids is generally recommended for the treatment of $\mathrm{AD}$; however, evidence suggests that once-daily application of some corticosteroids may be sufficient [59]. TCSs such as fluticasone propionate and methylprednisolone aceponate have demonstrated their efficacy with once-daily application $[60,61]$. Nevertheless, TCSs can be applied twice daily as an initial regimen, which can be reduced once the condition has improved.

\subsubsection{Treatment Duration}

TCSs are applied for 3 to 5 days until AD is controlled and for up to 2 weeks in moderate and severe AD [62].
The key symptom for evaluation of response is the improvement in pruritus, which allows for reduced frequency of application [63]. Various therapeutic options may be considered, since prescription habits are multiple and variable. Generally, for most topical TCSs, regardless of potency, application once or twice per day for 2 to 4 weeks [56] is recommended (Table 4).

\subsubsection{How to Apply TCSs}

TCSs must be applied on hydrated skin. They can be used together with emollient moisturizers, but their application on inflamed areas of the skin is recommended for approximately 15 minutes before an emollient moisturizer is used if the TCS is an ointment; if it is a cream, it can be applied after the emollient [63]. The use of an appropriate amount of TCS helps to reduce the occurrence of adverse effects. A standardized fingertip unit [64] has been devised to measure the amount of ointment necessary to cover specific anatomic areas adequately. Considered a valid method for the safe application of TCSs, 1 unit corresponds to the amount of ointment applied from the distal skin crease to the tip of the palmar aspect of the index finger, as shown in the Figure. One fingertip unit is approximately equivalent to $0.49 \mathrm{~g}$ of ointment and is required for adequate coverage of a specific skin area equivalent to both palms in adults $(2 \%$ of body surface area). 
Table 4. Recommendations and Key Points in the Use of Topical Corticosteroids in Atopic Dermatitis

- Topical corticosteroids are the main anti-inflammatory drugs in the acute phase of atopic dermatitis; they have a significant effect on the improvement of skin lesions compared with placebo.

- Adverse effects are generally mild and temporary.

- The recommended topical corticosteroids are those that present a better risk-benefit ratio. They should be applied correctly (fingertip unit), and potency should be assessed based on severity and the area to treat.

- Application of low potency topical corticosteroids on the face and neck. An intermediate-potency topical corticosteroid can be applied for short periods (3-5 days) in severe flares.

- Application of an intermediate or even a high-potency topical corticosteroid for short period (7-14 days) in delicate body areas such as the axilla or the inguinal fold.

- In severe or refractory atopic dermatitis, efficacy of topical corticosteroids may be increased using the wet wrap procedure with diluted topical corticosteroids, once per day for approximately 7 days; this is a relatively safe treatment in both children and adults.

- Avoid in children under 6 months of age.

- In pregnant women, use low-potency topical corticosteroids.

- The drugs should be applied once daily, except in more severe cases when they can be applied twice per day.

- "Proactive" treatment (twice weekly application) can improve long-term follow-up and reduce flares.

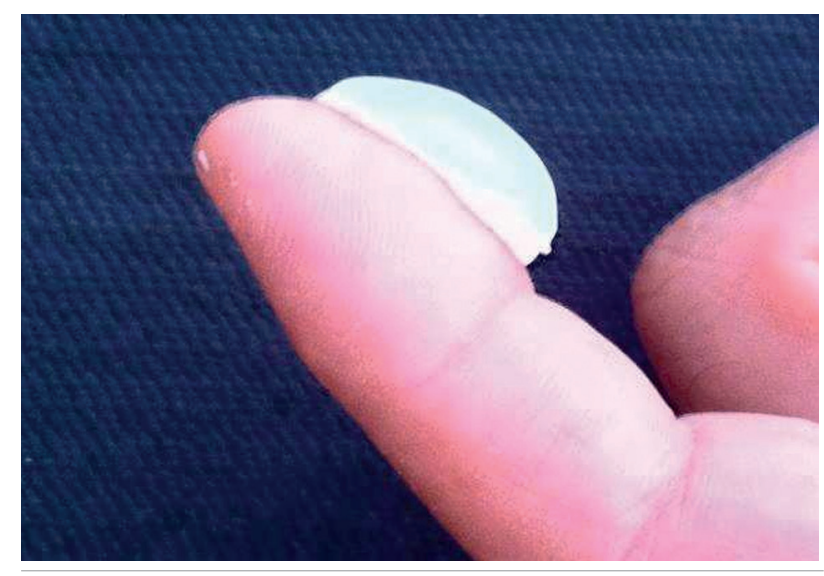

Figure. Correct method of applying the corticosteroid (fingertip unit).

\subsubsection{Wet Wrap Therapy}

The use of TCSs as wet wrap therapy is an option in recalcitrant cases [65]. A wet wrap acts as an occlusive barrier that facilitates the penetration of the TCS into the skin, thus increasing the amount of medication released to the affected areas [66]. In general, a double layer wrap (one layer impregnated with TCSs diluted to $10 \%$ with emollients covered by another, dry layer) is applied directly to the affected skin. This approach is recommended once daily for a mean (SD) of 7 days (2-14 days) in children with refractory or severe AD [65]. The use of wet wrap dressings with diluted TCSs has been found to be more efficacious as a short-term treatment in children with severe and/or refractory AD than wet wrap dressings with emollients only $[66,67]$. Leloup et al [68] recently demonstrated a significant improvement in the SCORAD value in children treated with wet wraps by applying fluticasone propionate diluted to $25 \%-50 \%$, together with an emollient, for more than 6 hours per night until erythema and pruritus disappear and, subsequently, maintaining the application twice or 3 times per week. Its efficacy in adult patients has also been demonstrated [69]. Appropriate explanation of the wet wrap technique and its application by nursing staff skilled in this type of therapy is of the utmost importance [68].

\subsubsection{Proactive Treatment}

Some studies suggest the beneficial effect of the preventative application of a potent TCS intermittently (twice weekly) and for an extended period to avoid flares of AD. The application of fluticasone propionate twice weekly $(0.05 \%$ cream or $0.005 \%$ ointment) [70] or methylprednisolone $(0.1 \%$ cream $)[56]$, together with daily emollient products, significantly reduces the risk of relapse of $\mathrm{AD}$ in children and adults.

\subsubsection{Topical Corticosteroids in AD and Pregnancy}

Only the application of low- or intermediate-potency TCSs is recommended. An association between the application of high-potency TCS and fetal growth restriction has been observed [71].

\subsubsection{Adverse Effects}

TCSs have been used in clinical practice since 1962, although data on their adverse effects are lacking, apart from those based on only a few weeks of treatment. However, TCSs are considered safe, with few adverse effects, when they are applied over long periods at the recommended doses and with low- or intermediate-potency preparations [56]. Although changes in the concentration of serum cortisol and even hypothalamic pituitary axis suppression following long-term treatment with TCSs have been reported in some studies [72,73], the application of TCSs at any potency for short periods does not produce clinically or statistically 
significant suppression of adrenal function $[74,75]$. Other potential adverse effects of TCSs include the occurrence of irritation at the application site, hypertrichosis, stretch marks, malar telangiectasia, acne, folliculitis, bacterial infection, skin atrophy, contact dermatitis, and glaucoma. The factors that predispose to cutaneous and systemic adverse effects are use of high-potency corticosteroids, long-term therapy with corticosteroids, application to highly permeable and/or large areas, occlusion, poor skin integrity, systemic diseases, and younger or older age. The risk of adverse effects of TCSs is a common concern for parents and caregivers of children with $\mathrm{AD}$ and may negatively affect adherence. Approximately $25 \%$ of patients are thought to avoid treatment for this reason $[58,67]$.

\subsubsection{Adverse Effects of Wet Wrap Therapy}

When TCSs are applied for a period of 2 to 14 days in children, temporary systemic bioactivity of the drugs is observed. This risk decreases if the amount of TCS is reduced, by applying it once daily or at a greater dilution [68]. Adverse effects such as folliculitis, refractory lesions in exposed areas, impetigo, and herpes infections may also appear, although these are considered uncommon [67].

\subsubsection{Contact Sensitization}

Contact sensitization should be taken into account whenever there is worsening or failure of skin lesions to respond to application of TCSs. Patch testing should be considered to determine hypersensitivity to the TCS itself or to a component of the vehicle. Prevalence is higher in the case of nonhalogenated corticosteroids than in halogenated corticosteroids. These drugs were considered contact allergen of the year in 2005 [76].

\subsection{Topical Calcineurin Inhibitors}

Tacrolimus (produced by Streptomyces tsukubaensis) and pimecrolimus (produced by Streptomyces hygroscopicus) belong to a new class of topical immunomodulators/ immunosuppressants known as calcineurin inhibitors [52]. Both drugs bind and inhibit the action of the protein calcineurin, which is implicated in the activation of T cells and inhibits the production of cytokines that participate in the inflammation that affects patients with AD. Their efficacy for short- and long-term use has been demonstrated in placebo-controlled clinical trials [77-79]. Calcineurin inhibitors are indicated as second-line treatment of AD that is not controlled with TCSs, when there is a significant risk of adverse effects due to their application, or when they are contraindicated [54]. Topical tacrolimus is available as a $0.03 \%$ and $0.1 \%$ ointment and topical pimecrolimus as a $1 \%$ cream. $0.1 \%$ tacrolimus is approved for the treatment of adult patients, whereas $1 \%$ pimecrolimus and $0.03 \%$ tacrolimus are approved in the treatment of children aged over 2 years [80] and adults [81]. Application in children under the age of 2 years is not recommended, although the safety and tolerance of $1 \%$ pimecrolimus in children aged 3-23 months has been reviewed for 2 years, with no reports of malignancy or signs of immunosuppression [82]. The antiinflammatory potency of $0.1 \%$ tacrolimus ointment is similar to that of intermediate-potency TCSs [83], whereas the latter are clearly more active than $0.03 \%$ tacrolimus ointment [84]. Two systematic reviews on the potency of topical tacrolimus $[84,85]$ concluded that $0.03 \%$ and $0.1 \%$ tacrolimus are superior to $1 \%$ hydrocortisone acetate or $1 \%$ pimecrolimus, as reported in a previous review [86]. Recommendations for calcineurin inhibitors in the treatment of AD are shown in Table 5.

\subsubsection{Indications and Application Methods}

Tacrolimus. In children, start with a $0.03 \%$ application, twice daily, for a maximum of 3 weeks. Subsequently, the application frequency must be reduced to once daily until visible lesions clear. According to the summary of product characteristics, in adult patients, $0.1 \%$ tacrolimus must be used from the start of the AD flares until clearance of the lesions $[87,88]$. The application of emollients must be postponed at least half an hour so that it does not interfere with the absorption of the drug. As a proactive treatment, the application of tacrolimus ointment is effective and safe up to 1 year to reduce the number of flares and improve the quality of life of both children and adult patients [89]. A maintenance regimen can be used with tacrolimus on 2 consecutive days weekly to prevent flares $[90,91]$. However, TCSs (fluticasone propionate) may be more effective in the prevention of $\mathrm{AD}$ flares than tacrolimus. More research into this area is warranted before a solid recommendation can be offered regarding the best therapeutic option [92].

$1 \%$ pimecrolimus. In patients with mild to moderate $\mathrm{AD}, 1 \%$ pimecrolimus used twice daily reduces itching and erythema 48 hours after starting treatment. If it is applied following the first signs of recurrence, it can reduce flares and the dose of TCSs used [93]. The long-term application of $1 \%$ pimecrolimus also has a preventative effect on flares and maintains the initial improvement in $\mathrm{AD}$; patients present only minimal residual lesions after 2 years $[25,80]$.

Table 5. Recommendations for Calcineurin Inhibitors in the Treatment of Atopic Dermatitis (Modified from Ring et al [43]

- They are more effective than placebo in the short- and long-term treatment of atopic dermatitis.

- They are specifically indicated in sensitive skin areas (face, skinfolds, anogenital region).

- $0.03 \%$ tacrolimus and $1 \%$ pimecrolimus are applied as second-line treatment in children aged over 2 years and adults with mildmoderate atopic dermatitis. $0.1 \%$ tacrolimus is only indicated in adults with moderate or severe atopic dermatitis.

- Tacrolimus has been effective as a proactive treatment (applied on 2 consecutive days weekly).

- Effective sun protection is recommended during the treatment period. 
Scientific evidence on the combined application of TCSs and TCIs is poor. Herbert et al [94] studied the use of $0.25 \%$ desoximetasone and $0.1 \%$ tacrolimus, twice daily, compared with tacrolimus and placebo, twice daily, in more than 80 adults with AD. Combined therapy was significantly more effective and presented adverse effects similar to those of the other groups. In addition, the pruritus and burning sensation associated with the application of tacrolimus were logically lower in the group receiving combined therapy. TCIs applied by wet wrap dressings could represent an alternative to the application of TCSs, as long as the data on their systemic absorption confirm that they do not reach immunosuppressive levels [95].

\subsubsection{Adverse Effects}

Both tacrolimus and pimecrolimus present a good safety profile [86]. The most common adverse effect is a burning sensation following application. In this respect, a comparative study in children with $0.03 \%$ tacrolimus and $1 \%$ pimecrolimus [96] showed better local tolerance to $1 \%$ pimecrolimus. Unlike TCSs, TCIs do not produce skin atrophy, which should be considered when the skin surface to treat is particularly delicate, such as the face or flexural areas. Generalized viral infections such as eczema herpeticum or eczema molluscatum have been observed during treatment with TCIs, although an increase in their frequency has not been demonstrated or has been shown to be only temporary in clinical trials [97,98]. In 2005, the United States Food and Drug Administration issued a warning regarding the potential relationship between these pharmacological agents and malignancies (especially lymphoma and skin cancer) based on the results of animal studies, case reports, and the knowledge of their mechanism of action $[99,100]$. Long-term data are needed on possible carcinogenicity, although, to date, no proof of a causal relationship has been reported [83,101]. Some authors consider that this recommendation and the minimum age for their application in children should be reviewed [101].

\section{Phototherapy}

Phototherapy consists of exposure to light by the application of UV rays. It is a second-line treatment for severe $\mathrm{AD}$ in adolescents and adults [102]. The beneficial action of phototherapy results from its anti-inflammatory effects and immunomodulating properties. In the treatment of $\mathrm{AD}$, the various modalities include narrowband UV-B therapy (NBUV-B), UV-A1, psoralen-UV-A (PUVA), wide-band UVA, broadband UVB, and the last two combined [103,104]. The results of various systematic reviews [105-106] support the use of UV-A1 phototherapy (340-400 nm) and NB-UV-B (311 $\mathrm{nm}$ ) in moderate to severe AD. Whereas NB-UV-B radiation is the preferred phototherapy modality for the treatment of patients with refractory $\mathrm{AD}, \mathrm{UV}-\mathrm{A} 1$ radiation, which is less widely available, may be more effective for the treatment of severe acute flare-ups in patients with AD [107,108]. The treatment regimen in this case would be to administer a short cycle of medium dose UV-A1 until improvement, followed by NB-UV-B. In general, UV-A1 is applied 3 times per week for at least 2 months (an average of 20-30 sessions) [104,106]. There is little evidence for the use of PUVA in patients with $\mathrm{AD}$, and it should be considered when NB-UV-B has not been effective [108]. Phototherapy in children with severe AD is moderately effective and generally well tolerated. The risk of long-term adverse effects is unknown; therefore, it should be limited to very severe cases that are refractory to other treatments [109-111]. Phototherapy is not recommended in pregnant women, as there is no evidence in this population group. Adverse effects may appear in the short term (acute pruritus and burns) and long term (premature skin ageing and increased risk of skin cancer). Appropriate equipment and trained personnel are needed for administration, thus limiting its use in some cases [112].

\section{Conclusions}

Treatment of AD can prove challenging, even for the most expert physician. Essential skin care in AD should be based on topical therapies that act against etiological mechanisms, diminish inflammation, improve pruritus, and prevent infection and local adverse effects. While we must focus on the management of acute AD flares, we need to establish an adequate long-term maintenance regimen and prophylactic approach. Although there are multiple and optimal topical options for the treatment of $\mathrm{AD}$, other innovative therapies are being investigated with the aim of reducing the severity of this disease, decreasing its activity, and improving the quality of life of patients with AD.

\section{Acknowledgments}

The authors wish to thank Sanofi Genzyme for translation support.

\section{Funding}

The authors declare that no funding was received for the present study.

\section{Conflicts of Interest}

The authors declare that they have no conflicts of interest.

\section{References}

1. Williams HC. Clinical practice. Atopic dermatitis. N Engl J Med. 2005:352:2314-24.

2. Odhiambo JA, Williams HC, Clayton TO, Robertson CF, Asher Ml. Global variations in prevalence of eczema symptoms in children from ISAAC Phase Three. J Allergy Clin Immunol. 2009; 124:1251-8.

3. Zheng T, Yu J, Oh MH, Zhu Z. The atopic march: progression from atopic dermatitis to allergic rhinitis and asthma. Allergy Asthma Immunol Res. 2011;3:67-73.

4. Egawa G, Kabashima K. Multifactorial skin barrier deficiency and atopic dermatitis: Essential topics to prevent the atopic march. J Allergy Clin Immunol. 2016;38:350-85. 
5. McAleer MA, Irvine AD. The multifunctional role of filaggrin in allergic skin disease. J Allergy Clin Immunol. 2013;131:28091.

6. Bieber T. Atopic dermatitis. N Engl J Med. 2008;358:1483-94.

7. Irvine $A D$, McLean $W H$, Leung DY. Filaggrin mutations associated with skin and allergic diseases. N Engl J Med. 2011;365:1315-27.

8. Lopes C, Rocha L, Sokhatska O, Soares J, Tavaria F, Correia O, et al. A Filaggrin Polymorphism Pro478Ser Is Associated With the Severity of Atopic Dermatitis and Colonization by Staphylococcal aureus. J Invest Allergol Clin Immunol. 2016:26:48-72.

9. Kilıç S, Sılan F, Hız MM, Işık S, Ögretmen Z, Özdemir Ö. Vitamin D Receptor Gene BSMI, FOKI, APAI, and TAQI Polymorphisms and the Risk of Atopic Dermatitis. J Invest Allergol Clin Immunol. 2016;26:106-10.

10. Eichenfield LF, Ellis CN, Mancini AJ, Paller AS, Simpson EL. Atopic dermatitis: epidemiology and pathogenesis update. Semin Cutan Med Surg. 2012;31:3-5.

11. Zaniboni MC, Samorano LP, Orfali Rl, Aoki V. Skin barrier in atopic dermatitis: beyond filaggrin. An Bras Dermatol. 2016:91:472-8

12. Werfel T, Allam JP, Biedermann T, Eyerich K, Gilles S, GuttmanYassky $E$, et al. Cellular and molecular immunologic mechanisms in patients with atopic dermatitis. J Allergy Clin Immunol. 2016;138:336-49.

13. Salimi M, Barlow JL, Saunders SP, Xue L, Gutowska-Owsiak D, Wang $X$, et al. A role for IL-25 and IL-33-driven type-2 innate lymphoid cells in atopic dermatitis. J Exp Med. 2013;2939-50.

14. Eyerich S, Eyerich K, Pennino D, Carbone T, Nasorri F, Pallotta $S$, et al. Th22 cells represent a distinct human T cell subset involved in epidermal immunity and remodeling. J Clin Invest. 2009;119:3573-85.

15. Roesner M, Heratizadeh A, Begemann G, Kienlin P, Hradetzky $\mathrm{S}$, Niebuhr M, et al. Der p1 and Der p2-Specific T Cells Display a Th2, Th17, and Th2/Th17 Phenotype in Atopic Dermatitis. J Invest Dermatol. 2015;135:2324-7.

16. Hijnen D, Knol EF, Gent YY, Giovannone B, Bejin SJ, Kupper TS, et al. CD8(+) T Cells in the Lesional Skin of Atopic Dermatitis and Psoriasis Patients Are an Important Source of IFN-gamma, IL-13, IL-17, and IL-22. J Invest Dermatol. 2013;133:973-6.

17. Miajlovic $H$, Fallon PG, Irvine AD, Foster TJ. Effect of filaggrin breakdown products on growth of and protein expression by Staphylococcus aureus. J Allergy Clin Immunol. 2010;126:1184-90.

18. Miyagaki T, Sugaya M. Recent advances in atopic dermatitis and psoriasis: genetic background, barrier function, and therapeutic targets. J Dermatol Sci. 2015;78:89-94.

19. LeBovidge JS, Elverson W, Timmons KG, Hawryluk EB, Rea C, Lee $\mathrm{M}$, et al. Multidisciplinary interventions in the management of atopic dermatitis. J Allergy Clin Immunol. 2016;138:32534.

20. Martindale. In: Pharma Editores. Guía completa de consulta farmacoterapéutica. 2008.

21. Lawton S. Safe and effective application of topical treatments to the skin. Nurs Stand. 2013;27:49-56.

22. Chamlin SL, Frieden IJ, Fowler A, Williams M, Kao J, Sheu M, et al. Ceramide- dominant, barrier-repair lipids improve childhood atopic dermatitis. Arch Dermatol. 2001;137:1110-2.
23. Lee HJ, Lee NR, Kim BK, Jung M, Kim DH, Moniaga CS, et al. Acidification of stratum corneum prevents the progression from atopic dermatitis to respiratory allergy. Exp Dermatol. 2017;26:66-72.

24. Huang JT, Abrams M, Tlougan B, Rademaker A, Paller AS. Treatment of Staphylococcus aureus colonization in atopic dermatitis decreases disease severity. Pediatrics. 2009:123:808-14.

25. Schneider L, Tilles S, Lio P, Boguniewicz M, Beck L, Lebovidge J, et al. Atopic dermatitis: A practice parameter update 2012. J Allergy Clin Immunol. 2013;131:295-9.

26. Mayser P, Kupfer J, Nemetz D, Schafer U, Nilles M, HortW, et al. Treatment of head and neck dermatitis with ciclopiroxolamine cream--results of a double-blind, placebo- controlled study. Skin Pharmacol Physiol. 2006;19:153-8.

27. Slutsky JB, Clark RA, Remedios AA, Klein PA. An evidencebased review of the efficacy of coal tar preparations in the treatment of psoriasis and atopic dermatitis. J Drugs Dermatol. 2010;9:258-64.

28. Hoare C, Li Wan Po A, Williams H. Systematic review of treatments for atopic eczema. Health Technol Assess. 2000;4:1-191.

29. Thami G, Sarkar R. Coal tar: past, present and future. Clin Exp Dermatol. 2002;27:99-103

30. Martín Mateos MA. Guía de Tratamiento de la dermatitis atópica en el niño. Ergon. Ed 2011.

31. Hon KL, Wong KY, Cheung LK, Ha G, Lam MC, Leung TF, et al. Efficacy and problems associated with using a wetwrap garment for children with severe atopic dermatitis. J Dermatolog Treat. 2007;18:301-5.

32. Nicol NH, Boguniewicz M, Strand M, Klinnert MD. Wet wrap therapy in children with moderate to severe atopic dermatitis in a multidisciplinary treatment program. J Allergy Clin Immunol Pract. 2014;2:400-6.

33. Andersen RM, Thyssen JP, Maibach HI. The role of wet wrap therapy in skin disorders - a literature review. Acta Derm Venereol. 2015;95:933-9.

34. Grether-Beck S, Felsner I, Brenden H, Kohne Z, Majora M, Marini $A$, et al. Urea uptake enhances barrier function and antimicrobial defense in humans by regulating epidermal gene expression. J Invest Dermatol. 2012;132:1561-72.

35. Åkerström U, Reitamo S, Langeland T, Berg M, Rustad L, Korhonen $L$, et al Comparison of Moisturizing Creams for the Prevention of Atopic Dermatitis Relapse: A Randomized Double-blind Controlled Multicentre Clinical Trial. Acta Derm Venereol. 2015:95:587-92.

36. Bigliardi PL, Stammer H, Jost G, Rufli T, Buchner S, Bigliardi-Qi $M$. Treatment of pruritus with topically applied opiate receptor antagonist. J Am Acad Dermatol. 2007;56:979-88.

37. Udkoff J, Waldman A, Ahluwalia J, Borok J, Eichenflield LF. Current and emerging topical therapies for atopic dermatitis. Clin Dermatol. 2017:35:375-82.

38. Gueniche A, Hennino A, Goujon C, Dahel K, Bastien P, Martin $R$, et al. Improvement of atopic dermatitis skin symptoms by Vitreoscilla filiformis bacterial extract. Eur J Dermatol. 2006;16:380-4.

39. Gueniche A, Knaudt B, Schuck E, Volz T, Bastien P, Martin $R$, et al. Effects of nonpathogenic gram-negative bacterium Vitreoscilla filiformis lysate on atopic dermatitis: a prospective, 
randomized, double-blind, placebo-controlled clinical study. Br J Dermatol. 2008;159:1357-63.

40. Seité S, Zelenkova H, Martin R. Clinical, Cosmetic and Investigational Dermatology. 2017;10:25-33.

41. Baumer W, Hoppmann J, Rundfeldt C, Kietzmann M. Highly selective phosphodiesterase 4 inhibitors for the treatment of allergic skin diseases and psoriasis. Inflamm Allergy Drug Targets. 2007;6:17-26.

42. Paller $A S$, Tom Wl, Lebwohl MG, Blumenthal RL, Boguniewicz M, Call RS, et al. Efficacy and safety of crisaborole ointment, a novel, nosteroidal phosphodiesterase 4 (PDE4) inhibitor for the topical treatment of atopic dermatitis (AD) in children and adults. J Am Acad Dermatol. 2016;75:494-503.

43. Eichenfield LF, Friedlander SF, Simpson El, Irvine AD. Assessing the New and Emerging Treatments for Atopic Dermatitis. Semin Cutan Med Surg. 2016;35:92-6.

44. Eichenfield LF, Call RS, Forsha DW, Fowler J Jr, Hebert AA, Spellman $M$, et al. Long-term safety of crisaborole ointment $2 \%$ in children and adults with mild to moderate atopic dermatitis. J Am Acad Dermatol. 2017;77:641-9.

45. Nygaard U, Vestergaard C, Deleuran M. Emerging Treatment Options in Atopic Dermatitis: systemic therapies. Dermatology. 2017;233:344-57

46. Bissonnette R, Papp KA, Poulin Y, Gooderham M, Raman M, Mallbris $L$, et al. Topical tofacitinib for atopic dermatitis: $A$ Phase 2a randomised trial. Br J Dermatol. 2016;175:902-11.

47. Nygaard U, Deleuran M, Vestergaard C. Emerging Treatment Options in Atopic Dermatitis: topical therapies. Dermatology. 2017;233:333-43

48. Guttman-Yassky E, Silverberg JI, Nemoto O, Forman SB, Wilke $A$, Prescilla $R$, et al. Baricitinib in adults with moderate-tosevere atopic dermatitis: a phase 2 parallel, double-blinded, randomized placebo-controlled multiple-dose study. J Am Acad Dermatol. 2018; Pii:S0190-9622(18)30129-4. [Epub ahead of print]

49. Stucker M, Pieck C, Stoerb C, Niedner R, Hartung J, Altmeyer P. Topical vitamin B12-a new therapeutic approach in atopic dermatitis-evaluation of efficacy and tolerability in a randomized placebo-controlled multicentre clinical trial. Br J Dermatol. 2004;150:977-83.

50. Nistico SP, Del Duca E, Tamburi F, Pignataro E, De Carvalho N, Farnetani $F$, et al. Superiority of a vitamin B12-barrier cream compared with standard glycerol-petrolatum-based emollient cream in the treatment of atopic dermatitis: A randomized, left-to-right comparative trial. Dermatol Ther. 2017;30.

51. Boada JN. Farmacología dermatológica. In: Floréz J, Armijo JN, Mediavilla A. Farmacología humana. Barcelona, Elsevier Masson E. 2008;1403.

52. Watson W, Kapur S. Atopic dermatitis. Allergy Asthma Clin Immunol. 2011;1:S4.

53. McHenry PM, Williams HC, Bingham EA. Management of atopic eczema. BMJ. 1995;310:843-7.

54. Wollenberg A, Oranje A, Deleuran M, Simon D, Szalai Z, Kunz B, et al. EFTAD/EADV Eczema task force 2015 position paper on diagnosis and treatment of atopic dermatitis in adult and paediatric patients. J Eur Acad Dermatol Venereol. 2016;30:729-47.

55. Eichenfield LF, Tom WL, Berger TG, Krol A, Paller AS, Schwarzenberger $K$, et al. Guidelines of care for the management of atopic dermatitis: section 2. Management and treatment of atopic dermatitis with topical therapies. J Am Acad Dermatol. 2014;71:116-32.

56. Tadicherla S, Ross K, Shenefelt PD, Fenske NA. Topical corticosteroids in dermatology. J Drugs Dermatol. 2009;8:1093-105.

57. Morley KW, Dinulos JG. Update on topical glucocorticoid use in children. Current opinion in pediatrics. 2012;24:121-8.

58. Wollenberg A, Barbarot $S$, Bieber $T$, Christen-Zaech $S$, Deleuran M, Fink-Warner A, et al. Consensus based European Guidelines for treatment of atopic eczema (atopic dermatitis) in adults and children: part I. J Eur Acad Dermatol Venereol. 2018:32:850-78

59. Williams HC. Established corticosteroid creams should be applied only once daily in patients with atopic eczema. BMJ. 2007;334:1272.

60. Woods MT, Brown PA, Baig-Lewis SF, Simpson EL. Effects of a novel formulation of fluocinonide $0.1 \%$ cream on skin barrier function in atopic dermatitis. J Drugs Dermatol. 2011;10:171-6.

61. Bieber T, Vick K, Folster-Holst R, Belloni-Fortina A, Stadtler $\mathrm{G}$, Worm $\mathrm{M}$, et al. Efficacy and safety of methylprednisolone aceponate ointment $0.1 \%$ compared to tacrolimus $0.03 \%$ in children and adolescents with an acute flare of severe atopic dermatitis. Allergy. 2007;62:184-9.

62. Callen J, Chamlin S, Eichenfield LF, Ellis C, Girardi M, Goldfarb $M$, et al. A systematic review of the safety of topical therapies for atopic dermatitis. Br J Dermatol. 2007;156:203-21.

63. Ring J, Alomar A, Bieber $T$, Deleuran $M$, Fink-Wagner $A$, Gelmetti $C$, et al. Guidelines for treatment of atopic eczema (atopic dermatitis) part I. J Eur Acad Dermatol Venereol. 2012;26:1045-60.

64. Long CC, Finlay AY. The finger-tip unit--a new practical measure. Clin Exp Dermatol. 1991;16:444-7.

65. Garnacho-Saucedo G, Salido-Vallejo R, Moreno-Gimenez JC. Atopic dermatitis: update and proposed management algorithm Actas Dermosifiliogr. 2013;104:4-16.

66. Goodyear HM, Spowart K, Harper Jl. 'Wet-wrap' dressings for the treatment of atopic eczema in children. Br J Dermatol. 1991;125:604.

67. Devillers AC, Oranje AP. Efficacy and safety of 'wet-wrap' dressings as an intervention treatment in children with severe and/or refractory atopic dermatitis: a critical review of the literature. Br J Dermatol. 2006;154:579-85.

68. Leloup P, Stalder JF, Barbarot S. Outpatient Home-based Wet Wrap Dressings with Topical Steroids with Children with Severe Recalcitrant Atopic Dermatitis: A Feasibility Pilot Study. Pediatr Dermatol. 2015;32:177-8.

69. Oranje AP, Devillers AC, Kunz B, Jones SL, DeRaeve L, Van Gysel $D$, et al. Treatment of patients with atopic dermatitis using wet-wrap dressings with diluted steroids and/or emollients. An expert panel's opinion and review of the literature. J Eur Acad Dermatol Venereol. 2006;20:1277-86.

70. Berth-Jones J, Damstra RJ, Golsch S, Livden JK, Van Hooteghem O, Allegra $F$, et al. Twice weekly fluticasone propionate added to emollient maintenance treatment to reduce risk of relapse in atopic dermatitis: randomised, double blind, parallel group study. BMJ. 2003;326:1367.

71. Chi CC, Kirtschig G, Aberer W, Gabbud JP, Lipozencic J, Karpati S, et al. Evidence- based (S3) guideline on topical 
corticosteroids in pregnancy. Br J Dermatol. 2011;165:943 52.

72. Walsh P, Aeling JL, Huff L, Weston WL. Hypothalamus-pituitaryadrenal axis supression by superpotent topical steroids. J Am Acad Dermatol. 1993;29:501.

73. Ellison JA, Patel L, Ray DW, David TJ, Clayton PE. Hypothalamicpituitary-adrenal function and glucocorticoid sensitivity in atopic dermatitis. Pediatrics. 2000;105:794-9.

74. Hengge UR, Ruzicka T, Schwartz RA, Cork MJ. Adverse effects of topical glucocorticosteroids. J Am Acad Dermatol. 2006;54:1-15.

75. Patel L, Clayton PE, Addison GM, Price DA, David TJ. Adrenal function following topical steroid treatment in children with atopic dermatitis. Br J Dermatol. 1995;132:950-5.

76. Isaksson M, Bruze M. Corticosteroids. Dermatitis. 2005; 16:3-5

77. Reitamo S, Wollenberg A, Schopf E, Perrot JL, Marks R, Ruzicka $T$, et al. Safety and efficacy of 1 year of tacrolimus ointment monotherapy in adults with atopic dermatitis. The European Tacrolimus Ointment Study Group. Arch Dermatol. 2000;136:999-1006.

78. Meurer M, Folster-Holst R, Wozel G, Weidinger G, Junger $\mathrm{M}$, Brautigam M. Pimecrolimus cream in the long-term management of atopic dermatitis in adults: a six-month study. Dermatology. 2002; 205:271-7.

79. Ruzicka T, Bieber T, Schopf E, Rubins A, Dobozy A, Bos JD, et al. A short-term trial of tacrolimus ointment for atopic dermatitis. European Tacrolimus Multicenter Atopic Dermatitis Study Group. New Eng J Med.1997;337:816-21

80. Wahn U, Bos JD, Goodfield M, Caputo R, Papp K, Manjra A, et al. Efficacy and safety of pimecrolimus cream in the longterm management of atopic dermatitis in children. Pediatrics. 2002;110:2.

81. Harper J, Green A, Scott G, Gruendl E, Dorobek B, Cardno M, et al. First experience of topical SDZ ASM 981 in children with atopic dermatitis. Br J Dermatol. 2001;144:781-7.

82. Paul C, Cork M, Rossi AB, Papp KA, Barbier N, de Prost Y. Safety and tolerability of $1 \%$ pimecrolimus cream among infants: experience with 1133 patients treated for up to 2 years. Pediatrics. 2006;117:18-28

83. Reitamo S, Rustin M, Ruzicka T, Cambazard F, Kalimo K, Friedmann PS, et al. Efficacy and safety of tacrolimus ointment compared with that of hydrocortisone butyrate ointment in adult patients with atopic dermatitis. J Allergy Clin Immunol. 2002;109:547-55.

84. Chen SL, Yan J, Wang FS. Two topical calcineurin inhibitors for the treatment of atopic dermatitis in pediatric patients: a meta-analysis of randomized clinical trials. J Dermatol Treat. 2010:21:144-56.

85. Yan J, Chen SL, Wang XL, Zhou W, Wang FS. Meta-analysis of tacrolimus ointment for atopic dermatitis in pediatric patients. Pediatr Dermatol. 2008;25:117-20.

86. Ashcroft DM, Dimmock P, Garside R, Stein K, Williams HC. Efficacy and tolerability of topical pimecrolimus and tacrolimus in the treatment of atopic dermatitis: meta- analysis of randomised controlled trials. BMJ. 2005;330:516.

87. Torrelo A. Topical tacrolimus in atopic dermatitis in children. Actas Dermosifiliogr. 2008;99:14-8.

88. Ortiz de Frutos FJ. Atopic dermatitis and tacrolimus in adults. Actas Dermosifiliogr. 2008;99:8-13.
89. Wollenberg A, Reitamo S, Atzori F, Lahfa M, Ruzicka T, Healy E, et al. Proactive treatment of atopic dermatitis in adults with 0.1\% tacrolimus ointment. Allergy 2008;63:742-50.

90. Healy E, Bentley A, Fidler C, Chambers C. Cost-effectiveness of tacrolimus ointment in adults and children with moderate and severe atopic dermatitis: twice-weekly maintenance treatment vs. standard twice-daily reactive treatment of exacerbations from a third-party payer (U.K. National Health Service) perspective. Br J Dermatol. 2011;164:387-95.

91. Williams HC. Preventing eczema flares with topical corticosteroids or tacrolimus: which is best? $\mathrm{Br} J$ Dermatol. 2011;164:231-3.

92. Schmitt J, von Kobyletzki L, Svensson A, Apfelbacher C. Efficacy and tolerability of proactive treatment with topical corticosteroids and calcineurin inhibitors for atopic eczema: systematic review and meta-analysis of randomized controlled trials. Br J Dermatol. 2011;164:415-28.

93. Eichenfield LF, Thaci D, de Prost Y, Puig L, Paul C. Clinical management of atopic eczema with pimecrolimus cream 1\% (Elidel) in paediatric patients. Dermatology. 2007;215:3-17.

94. Hebert AA, Koo J, Fowler J, Berman B, Rosenberg C, Levitt J. Desoximetasone $0.25 \%$ and tacrolimus $0.1 \%$ ointments versus tacrolimus alone in the treatment of atopic dermatitis. Cutis. 2006;78:357-63.

95. Shainhouse T, Eichenfield LF. Long-term safety of tacrolimus ointment in children treated for atopic dermatitis. Exp Opin Drug Safety. 2003;2:457-65.

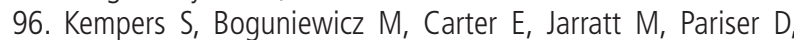
Stewart $D$, et al. A randomized investigator-blinded study comparing pimecrolimus cream $1 \%$ with tacrolimus ointment $0.03 \%$ in the treatment of pediatric patients with moderate atopic dermatitis. J Am Acad Dermatol. 2004;51:515-25.

97. Braham SJ, Pugashetti R, Koo J, Maibach HI. Occlusive therapy in atopic dermatitis: overview. J Dermatol Treat. 2010;21:62-72.

98. Wetzel S, Wollenberg A. Eczema molluscatum in tacrolimus treated atopic dermatitis. Eur J Dermatol. 2004;14:73-4.

99. https: // www.fda.gov/Drugs/DrugSafety/ PostmarketDrugSafetyInformationforPatientsandProviders/ ucm153524.htm.

100. https: // www.fda.gov/Drugs/DrugSafety/ PostmarketDrugSafetylnformationforPatientsandProviders/ ucm 107845.htm.

101. Luger $T$, Boguniewicz $M$, Carr $W$, Cork $M$, Deleuran $M$, EichenfieldL, et al, Pimecrolimus in atopic dermatitis: Consensus on safety and the need to allow use in infants. Pediatr Allergy Immunol. 2015;26:306-15.

102. Akdis CA, Akdis M, Bieber T, Bindlev-Jensen C, Boquniewicz $M$, Eigenmann $P$, et al. Diagnosis and treatment of atopic dermatitis in children and adults: European Academy of Allergology and Clinical Immunology/American Academy of Allergy, Asthma and Immunology/PRACTALL Consensus Report. Allergy. 2006;61:969.

103. Gambichler T. Management of atopic dermatitis using photo(chemo)therapy. Arch Dermatol Res. 2009;30:197.

104. Lubbe J. Practice experience with topical calcineurin inhibitors. Hautarzt. 2003;54:432-9.

105. Meduri NB, VandergriffT, Rasmussen H, Jacobe H. Phototherapy in the management of atopic dermatitis: a systematic review. Photodermatol Photoimmunol Photomed. 2007;23:106. 
106. Perez-Ferriols A, Aranegui B, Pujol-Montcusí JA, MartínGorgojo A, Campos-Domínguez M, Feltes RA, et al. Phototherapy in Atopic Dermatitis: A Systematic Review of the Literature. Actas Dermosifiliogr. 2015;106:387-401.

107. Garritsen FM, Brouwer MW, Limpens J, Spuls PI. Photo(chemo) therapy in the management of atopic dermatitis: An updated systematic review with implications for practice and research. Br J Dermatol. 2014;170:501-13.

108. Ling TC, Clayton TH, Crawley J, Exton LV, Goulden V, Ibbotson $S$, et al. British Association of Dermatologists and British Photodermatology Group guidelines for the safe and effective use of psoralen-ultraviolet A therapy 2015. Br J Dermatol. 2016;174:24-55.

109. Reynolds NJ, Franklin V, Gray JC, Diffey BL, Farr PM. Narrowband ultraviolet B and broad-band ultraviolet A phototherapy in adult atopic eczema: a randomised controlled trial. Lancet. 2001;357:2012.

110. Jury $C S$, McHenry $P$, Burden $A D$, Lever $R$, Bilsland $D$. Narrowband ultraviolet $B$ (UVB) phototherapy in children. Clin Exp Dermatol. 2006;31:196.
111. Clayton TH, Clark SM, Turner D, Goulden V. The treatment of severe atopic dermatitis in childhood with narrowband ultraviolet B phototherapy. Clin Exp Dermatol. 2007;32:28.

112. Ring J, Alomar A, Bieber $T$, Deleuran M, Fink-Wagner $A$, Gelmetti $C$, et al. Guidelines for treatment of atopic eczema (atopic dermatitis). Part II. J Eur Acad Dermatol Venereol. 2012;26:1176-93.

\section{Manuscript received February 22, 2018; accepted for publication July 13, 2018.}

\section{Lys Herráez}

Hospital Universitario 12 de Octubre

Madrid, Spain

E-mail: lysherraez@hotmail.com 